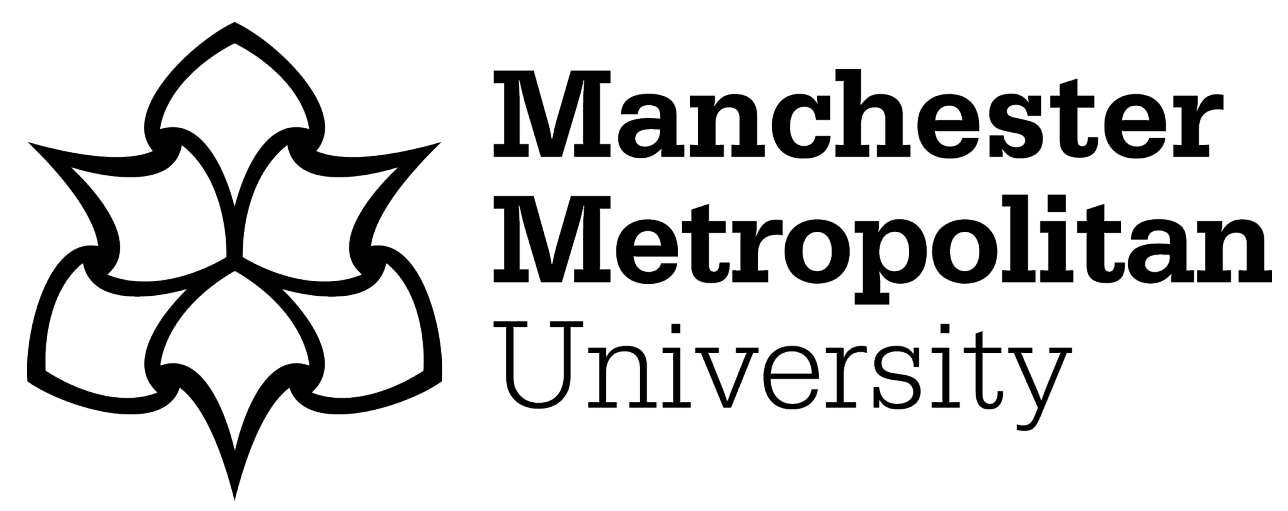

Silva, LV, Anholon, R, Rampasso, IS, Silva, D, Quelhas, OLG, Leal Filho, W and Santa-Eulalia, LA (2020) Critical analysis of organizational change process: evidences from a steel company. Business Process Management Journal, 26 (6). pp. 1525-1540. ISSN 1463-7154

Downloaded from: https://e-space.mmu.ac.uk/624965/

Version: Accepted Version

Publisher: Emerald

DOI: https://doi.org/10.1108/BPMJ-05-2019-0199

Please cite the published version 


\title{
Critical analysis of organizational change process: evidences from
}

a steel company

Silva LV, Anholon R, Rampasso IS, Silva D, Quelhas OLG, Leal Filho, W. et al.

Business Process Management Journal 01 Jan 2019

https://www.emerald.com/insight/content/doi/10.1108/BPMJ-05-2019-

\section{$\underline{0199 / \text { full/html }}$}

Silva LV, Anholon R, Rampasso IS, Silva D, Quelhas OLG, Leal Filho, W. et al., Business Process Management Journal, 2019

\begin{abstract}
Purpose: The objective of this article was to evaluate the main factors that influence the organizational change in a steel company.

Design/methodology/approach: The methodological procedures used were literature review and survey. The literature review allowed the listing of 24 factors and theses were grouped into three constructs (Behavioral Aspects, Cultural Aspects and Management Aspects). The survey allowed the quantification of each factors based on information provided by employees who work in mentioned company. The data collected were analyzed using the PLS-SEM technique.

Findings: For the Behavioral Aspects, the following factors were validated: 1) fear of the unknown; 2) insecurity and anxiety; 3) stress and feeling of suffering. For the Cultural Aspects
\end{abstract}


the following factors were validated: 1) multicultural in the company; 2) low degree of risk acceptance and low performance acceptance; 3) excessive concerns about consensus. Finally, for the Management Aspects, the following factors were validated: 1) lack of clarity in communications; 2) lack of alignment of goals; 3) lack of leadership engagement.

Originality/value: The results are valuable for the company studied and for other managers interested in subject. The findings presented here can broaden the debate about this topic and contribute with professional that wish to evaluate the mentioned factors.

Keywords: Business administration; Organizational change; Steel company; Structural Equations Modeling. 


\section{Introduction}

The constant variations in the demands and the client specifications require more agile management forms from organizations. In this context, Leitão and Domenico (2015) consider the organizational change process to be an indispensable phenomenon that guides companies to long-term survival. This process creates value and renews habits and beliefs. And, as a business process, organizational change can be understood as a set of activities developed by organizations to reach a target (Lee and Dale, 1998; Sidorova and Isik, 2010; Veit et al., 2017).

Many approaches and methods have been suggested to manage the process of organizational change. However, it is important to highlight that there is no ideal method that addresses all situations. The process of organizational change is associated to the organization context, hierarchical structure, culture and strategies involved. Organizational change therefore, becomes a complex process (Al-Haddad and Kotnour, 2015; Alavi and Gill, 2017; Jacobs et al., 2013; Soparnot, 2011).

Although organizations change frequently for improved performance, the reality shows that most organizational change programs fail. Researchers as Al-Haddad and Kotnour (2015) and Jansson (2013) argue that the success rate for these kinds of initiatives is less than $30 \%$.

Smith and Mourier (1999) have pointed out that most organizational change efforts fail during the implementation phase. According to them, the implementation involves a lot of activities such as planning, acquisition, installation of resources and technology, preparation of employees for the change and scheduling of events. Erwin and Garman (2010) and Maheshwari and Veena Vohra (2015) mention that one of the main reasons for failure is an inadequate approach to the people involved. People's behavior and psychological responses are recognized as key elements in the process of change. For some people, change can bring satisfaction and advantages, while for others the same change can bring pain, stress, and disadvantages (Abdul 
Rashid et al., 2004; Drummond et al., 2017; Smollan, 2014). Van Knippenberg, Martin and Tyler (2006) argue that the success of implementing change depends on the willingness of the people involved to change their behavior, attitudes, values and goals.

The reality is present in companies of different segments, including steel industry organizations. In order to be more competitive, these companies need to continually improve processes and management practices thereby causing organizational changes. Many factors will influence the processes of change and their identification can help managers to reach better results. This article presents a study carried out in a company in the steel sector in order to evaluate the main factors that influence the processes of organizational change and it can contribute to the debates related to the theme.

Additionally, this article presents four further sections. The second section presents the theoretical basis, in which it is pointed out that 24 factors influence the organizational change processes. The third section demonstrates the methodological procedures used to conduct the research. Section four presents the results obtained and the discussions. Finally, Section Five presents the main conclusions.

\section{Theoretical Bases}

There are many factors that influence the processes of organizational change and the understanding of them can help managers achieve better results. In general, organizational changes are influenced by three types of aspect: behavioral, cultural and management. The presentation of the theoretical basis was organized in these three categories, as shown below. 


\section{Behavioral aspects}

According to Bordia, Hobman, Jones, Gallois and Callan (2004) and Smollan (2014), organizational changes are accompanied by uncertainties and promote feelings of insecurity, anxiety, sadness and stress in members whose job or position are at risk. By this, $\mathrm{Xu}$, Payne, Horner and Alexander (2016) argue that the analysis of individuals' psychological predispositions is an important element in the management of organizational change. It is necessary to understand the conditions that individuals are willing to face (Lewis, 1994).

Canning and Found (2015) noted that a positive feeling about the changes contributes to success; when it is not present, it is possible to see resistance. Erwin and Garman (2010) described an idea of a "three-dimensional attitude in the direction of change", contemplating interaction between cognitive, affective and behavioral aspects. To them, the psychological variables influence individuals in the ability to adapt to the changes.

Based on the argument that one of the main obstacles to change is related to the "fear of the unknown" or "abnormal situation", the cognitive model can be approached first. When a person has information and knowledge about potential changes, their feelings can be changed positively to achieve success (Abdul Rashid et al., 2004).

According to Luscher, Lewis and Ingram (2006) the resistance in the processes of change arises because people do not perceive the benefits to themselves or to the group, so the participation and commitment of managers is important in order to reduce resistance. Tiong (2005) cited by Maheshwari and Veena Vohra (2015) agree with this point of view and highlight the importance of employee welfare during organizational change. Good welfare reduces stress and motivates employees to work efficiently. When this relationship is established, confidence increases and fear is reduced. 
Seo et al. (2012) makes an interesting analysis regarding the engagement of employees in organizational change processes. Overall, committed employees show a high degree of commitment and are prepared to make sacrifices. Employees who are not engaged, in turn, have a low degree of commitment, are not interested in participating and have a negative feeling about the organizational change process. Behaviors such as frustration, anger and fear are examples of negative emotions during organizational changes. Some people remain silent for fear of negative personal or professional consequences. On the other hand, positive emotions such as enthusiasm can contribute significantly to the success of any change (Choi, 2011; Jansson, 2013; Van Knippenberg et al., 2006; Lewis, 1994; Smollan, 2014)

Abdul Rashid et al. (2004) argue that resistance to change can originate from a single factor or combination of them, such as changes in work routine, economic security imbalance, reduction of status, etc. Briody, Meerwarth Pester and Trotter (2012) and Seo et al. (2012) agree with the point of view mentioned and argue that negative experiences with organizational change processes can also generate resistance. Thus, analysis of the past organizational changes can indicate how people will react to future changes.

For Gover, Halinski and Duxbury (2015), the length of time that the employee works in the company can also contribute to increasing resistance since it increases the probability that the employee has experienced some negative aspect of change. On the other hand, Harris and Ogbonna (1998) affirm that resistance to change is not necessarily related to the length of time that the person acts in an organization, but to the length of time that the employee has worked performing the same function. 


\section{Cultural aspects}

According to Canning and Found (2015) the organizational culture is composed of historical factors, business segment, traditions and values of the organization. The union of these factors promotes the collective mind of the organization. For Jacobs et al. (2013), much research about organizational change still ignores the influence of company culture.

There are other considerations about organizational culture presented in the literature. According to Abdul Rashid et al. (2004), organizational culture is composed of values, beliefs and assumptions. The members of an organization share and practice the culture as expected behavior. Soparnot (2011) describes culture as a symbolic structure, which acts as a reference for the improvement implementations and understanding of involvement at employee level.

According to Van Knippenberg et al. (2006) an important point in the culture is the relationship that employees develop with the organization. It is important to identify the individuals who are focused only on the benefits and not on the processes of change. On the other hand, individuals who strongly identify with the organization will be more focused on those processes and will develop a positive stance (Jacobs et al., 2013).

Seo et al. (2012) and Rivera, Domenico and Sauaia (2014) argue that during the initial phase of the change process, managers need to emphasize motivational aspects, because even the most engaged and positive employees can develop negative behaviors. In fact, when there is a positive and participatory culture, collective actions will converge towards main goals and will provide a greater degree of legitimacy to change (Cesar, 2006; Soparnot, 2011). Choi (2011) adds that the existence of successful cases of change in the company promotes participation and involvement of employees.

Nery and Neiva (2015) mention that companies with low risk tolerance also have low acceptance of change. In the same line mentioned above, Berkhout (2012) found that companies 
with strong risk management have better results related to organizational change. On the other hand, Abdul Rashid et al. (2004) argue that people are less tolerant of change if the organizational culture promotes an exaggerated concern for consensus.

Finally Canning and Found (2015) mention that the changes will be effective if they are linked to the organizational culture. The potential for change is associated with goals and measures, customs and norms, ceremonies and events, management behaviors, rewards and acknowledgements, physical environment and organizational structure.

\section{Management Aspects}

The challenge of leadership in managing change is a topic researched in different ways, considering implementation, action and control of the process (Bhatnagar et al., 2010; Erwin and Garman, 2010; Jacobs et al., 2013; Van Knippenberg et al., 2006). Human Resources professionals have a relevant role in this sense since they can help managers support the changes and reach better performance (Choi, 2011; Kalyani and Prakashan Sahoo, 2011). Maheshwari and Veena Vohra (2015) and Will (2015) suggest that Human Resources professionals must be involved in all organizational processes related to change.

It is very common for different ideas to exist between managers and employees during the processes of organizational change and, in this context, efficient communication becomes essential. For Erwin and Garman (2010) and Bueno (2005) communication is a relevant element in organizational changes, because from it the process can be correctly directed to an effective result. Canning and Found (2015) and Smollan (2015) also point out that communication plays a significant role in accepting change. The communication needs to be frequent and precise to 
reduce uncertainties related to the changes such as fear and anxiety of the employees (Erwin and Garman, 2010; Van Knippenberg et al., 2006; Seo et al., 2012; Xu et al., 2016).

Foster (2010) adds that techniques such as feedback and training increase the information interpretation and likelihood of acceptance to change. According to Canning and Found (2015), for a change to be successful it is necessary to develop a positive mindset in the organization, stimulate new ideas, provide feedback, share information and give employees decision-making authority.

The integration of the team during the change process and the alignment with the management makes the situation favorable and provides increased trust between the team and the leadership (Erwin and Garman, 2010; Seo et al., 2012). In line with the statements, Smollan (2014) argue that acceptance of change is greater when managers recognize the positive feelings of change. In addition, engaging team members in problem-solving increases the probability of success and provides better job satisfaction and results (Bhatnagar et al., 2010; Canning and Found, 2015; Cesar, 2006; Erwin and Garman, 2010; Soparnot, 2011).

For Seo et al. (2012) management based on leadership and trust contributes to better results in organizational change. Understanding employees' attitudes and their level of understanding about change should be the first step taken by managers. Unfortunately, in most companies, the changes are imposed and bring negative perceptions by the team (Foster, 2010; Orsi, 2006; Pitsakis et al., 2012; Will, 2015).

For Al-Haddad and Kotnour (2015) and Gover et al. (2015) many approaches and methods have been suggested to manage the change process, however, each organization has unique characteristics and conditions (differences in structural levels, control systems and methods, strategies, human resources, etc.). It is necessary to understand the company context and values. 
Synthesis of the factors that influence the processes of organizational change

Based on the information previously reported, it was possible to list 24 factors that influence organizational change processes. These factors are presented in three constructs, as shown in Table 1. In the same table are presented the nomenclatures that will be used in statistical data analyzes.

\section{Table 1 position}

\section{Methodological procedures}

The research began with the literature review and the terms used to find articles in scientific bases were "organizational change", "critical factors", "process critical", "strategy" and "competitiveness". The research was carried out considering a horizon of 20 years and returned 138 articles. Studying these 138 articles, it was possible to note that 75 articles referred to factors that influence organizational change and they were used. The analysis of these 75 articles allowed listing 24 factors in three main constructs, as shown in Table 1. These factors were used to structure the questionnaire used in the survey.

Once the questionnaire was structured, it was submitted to a pre-test with a professor of engineering, a psychologist and a manager, in order to identify and correct any mistakes. The professor has over 15 years of experience in cultural changing processes and teaches subjects related to industrial management. The psychologist works in the steel company and has 20 years of experience and is an expert in behavior analysis and recruiting people; she has experience as people development manager in a large company. The manager is a human resource manager in the steel company, with more than 20 years of experience in the area. The choice of two 
experts from the steel company was to ensure that they would know the reality of the respondents to evaluate the questionnaire. The professor was selected to evaluate the accuracy of the content. It is important to point out that the project research and questionnaire was submitted to an Ethics Research Committee for validation.

Each of the 24 factors presented in Table 1 was analyzed by employees of the steel company using a scale from 0 to 10 , in which $0=$ a non-observed factor and $10=$ an intense factor observed during the organizational changes. The data were collected over two months and analyzed through Partial Least Squares - Structural Equations Modeling (PLS-SEM). A statistical technique appropriated for researches on social sciences (Hair et al., 2014; Kala Kamdjoug et al., 2018). The data analysis used the nomenclatures presented in Table 1. The steps for PLS-SEM data analysis followed the recommendations of Ringle et al. (2014) and are presented below.

It worth to highlight that the steel company was selected because it undergone several organizational changes throughout the years and there are employees that experienced at least one of these changes, as it will be detailed in the results section. Currently, the company has 1400 employees. Thus, the steel company characterizes an interesting environment to investigate the main factors that influence the organizational change.

\section{Step 1: Definition of the model}

According to Ringle et al. (2014), there are many situations in applied social sciences research in which the data do not show adherence to a normal multivariate distribution. There are situations where the models are extremely complex and contain many constructs and variables. In addition, there are occasions when models are little explored. In these situations, it is recommended to use SEM based on variance or Partial Least Square (PLS) estimation 
models. In this method, the correlations between the constructs and their observed variables are calculated and the linear regressions are performed.

\section{Step 2: Calculation for the minimum sample size required.}

The subsequent step is to calculate the sample size required. Ringle et al. (2014) recommend the use of the software $G^{*}$ Power 3.1.9 with the following parameters: power of the test $80 \%$ and median effect size $15 \%$.

Step 3: application of the Partial Least Squares (PLS) method.

With the determination of the model and based on the parameters recommended Ringle et al. (2014), the model can be simulated. The recommended parameters for this simulation are: "Path Weighting Scheme", default of the model: variance 0 and standard deviation $=1$; maximum number of rotations to converge the model $=500$; stopping criterion of the calculations $=0.00001$. This simulation generates a report to be analyzed in subsequent phases.

Step 4: evaluation of the Average Variance Extracted (AVE).

At this stage, Ringle et al. (2014) suggest the use of the Henseler criterion (Henseler et al., 2009) for analysis of AVEs. This indicator should be greater than 0.50. The AVE can be understood as the portion of the data that explains how much the variables are correlated with their respective constructs. AVEs smaller than 0.50 indicate the need to withdraw some variables from the construct and re-analyze the resulting model.

Step 5: evaluation of Cronbach's Alpha coefficient (CA) and Composite Reliability (CC) coefficient. 
These parameters are used to verify if data are reliable and free of bias. The CA is based on the interactions of the variables and is very sensitive to the number of variables that compose the construct. The $\mathrm{CC}$, in turn, prioritizes the variables according to their reliabilities. For Hair et al. (2014), values above 0.60 for $\mathrm{AC}$ and above 0.70 for $\mathrm{CC}$ are considered satisfactory and Ringle et al. (2014) suggest that CC is more adequate for SEM.

Step 6: Evaluation of the Pearson determination coefficients

This index evaluates how much the construct can be explained by the structural model, indicating the quality of the adjusted model. In the case of behavioral sciences, Cohen (1988) suggests that $\mathrm{R}^{2}=2 \%$ is classified as a small effect, $\mathrm{R}^{2}=13 \%$ as a median effect and $\mathrm{R}^{2}=26 \%$ as a large effect. Many different behaviors are observed during the processes of organizational change.

Step 7: Evaluation of the discriminant validity using the criteria of Cross Loads and Fornell and Larcker.

The purpose here is to determine if the constructs are independent and if the variables are located in the most appropriate construct. Ringle et al. (2014) present two criteria for this purpose. The first one, Chin (1998) criterion for cross loads, defines that the factor loads of each variable must be higher in their constructs than in the other constructs. The second was developed by Fornell and Larcker (1981); it argues that the square root of the AVEs of each construct must be greater than the correlations between the constructs.

Step 8: Evaluation of the significance of linear correlations and regressions

This evaluation aims to verify if it is possible to use linear regression and correlation in SEM. For this, a technique called bootstrapping is used. Correlations and regressions will be 
considered valid if t-student values calculated are greater than 1.96. This step is important since bootstrapping evaluates not only the correlations but also the causality.

Step 9: Evaluation of relevance or predictive validity parameters $\left(Q^{2}\right)$

The $\mathrm{Q}^{2}$ is obtained through the analysis of general redundancy and evaluates how close the model is to what was expected of it. In summary, this indicator assesses the accuracy of the adjusted model and, according to Hair et al. (2014) should have values above zero.

\section{Step 10: Evaluation of Effect Size or Cohen Indicator $\left(f^{2}\right)$}

According to Ringle et al. (2014), this parameter is also related to the quality of the model. It is obtained by the analysis of commonalities and evaluates how much each construct is useful for the adjustment of the model. For the area of administrative sciences, Hair et al. (2014) recommends values of $\mathrm{f}^{2}$ above 0.15 .

After the steps previously presented, it was possible to obtain the model with variables that represent the consensus of the company in relation to the factors that impact the processes of organizational change. Finally, debates and analysis were carried out.

\section{Results and debates}

Based on literature review, a model (step 1) was proposed in which variables are divided in three in major constructs: Behavioral Aspects, Cultural Aspects and Management Aspects. The initial model proposed is presented by Figure 1.

\section{Figure 1 position}


The subsequent step was characterized by the calculation of the minimum sample size (step 2) and, by the software, this number was 55 respondents. The authors of this article collected information from 158 employees who work in the company and therefore, the sample is satisfactory. It is worth presenting some characteristics of this sample: $78 \%$ of the respondents had already participated in change processes more than once, $42 \%$ are older than 41 years of age, $59 \%$ have more than 11 years of employment within the company, $30 \%$ are in leadership and $71 \%$ are at operational level. These data demonstrate that the respondents have knowledge about what is involved in a change process, are of an age considered to be mature as a professional and have been working in the company for a long time knowing the company customs.

Step 3 was characterized by the application of the PLS method and the model was validated after some interactions. In order to obtain the final model, it was necessary to eliminate some variables, leaving the constructs with AVEs higher than 0.5 (step 4). This procedure is recommended by (Ringle et al., 2014). Figure 2 shows the validated model.

\section{Figure 2 position}

The reliability of the obtained model (step 5) was analyzed. This analysis was done using Cronbach's Alpha coefficient (CA) and Composite Reliability (CC) coefficient. The quality of the adjusted model was also analyzed using the Pearson determination coefficient $\left(\mathrm{R}^{2}\right.$, step 6$)$. In Table 2 it is possible to note that the Cronbach's Alpha coefficient, Composite Reliability and $\mathrm{R}^{2}$ values are adequate (see criteria used in section 3 ).

\section{Table 2 position}


In step 7 discriminant validities were verified, using two criteria. Table 3 shows the results of the criteria proposed by Chin (1998), in which it is possible to observe that the variables present higher factor loads in their original constructs. Table 4 also presents the results positive for the criteria of Fornell and Larcker (1981).

\section{Table 3 position}

\section{Table 4 position}

In step 8 , resampling tests were performed in order to verify the significance of linear correlations and regressions. Resampling simulations were done 500 times by the software. For Ringle et al. (2014) the significance of linear correlations and regressions are satisfactory for values above $95 \%$, which corresponds to t-student values above 1.96 . Table 5 shows these valued in all relationships.

\section{Table 5 position}

Following sequence, Relevance or Predictive Validity $\left(\mathrm{Q}^{2}\right)$ values (step 9) and Effect Size $\left(\mathrm{f}^{2}\right)$ or Cohen Indicator (step 10) were evaluated. These indices are used to evaluate the quality of the model, according to Ringle et al. (2014). Table 6 presents the values of $\mathrm{Q}^{2}$ and $\mathrm{f}^{2}$ indicating the accuracy of the model and how much the constructs are important for the model (see criteria used in section 3)

\section{Table 6 position}

With the accomplishment of the previous steps, it was possible to validate the model and identify the main factors observed in organizational changes in the steel company analyzed. 
Table 7 presents the factors validated by the SEM. Complementarily, the same table also shows the averages obtained. These averages allow analysis of the intensity of each factor observed.

\section{Table 7 position}

With validation, it was possible to identify the main factors that influence changes in the company analyzed. These factors represent the common factors, indicating that the interviewees' perception converges to them. The validated factors in the Behavioral Aspects Construct indicate that, during the last processes of change, fear, insecurity, anxiety, stress and feelings of suffering were present in the company according to the consensus. This situation is corroborated by Bordia et al. (2004) that argues that changes promote uncertainties and inaccuracies and favor feelings as insecurity, anxiety, sadness and stress.

The validated factors in the construct Cultural Aspects show the existence of different cultures coexisting in the company, the low degree of acceptance to risk, the acceptance of low performance and the excessive concern with consensus. The existence of multiculturalism reflects the fact that the company has gone through 2 mergers in a decade and had various changes in stock control. Another validated factor was "low degree of risk acceptance". For Nery and Neiva (2015), companies with low tolerance to risks usually present low acceptance to changes. The authors of this article believe that the acceptance of low performance and excessive preoccupation with the consensus can be a result of the mixture of different cultures, a proposition corroborated by Abdul Rashid et al. (2004).

Finally, the factors "lack of clarity in communications", "lack of alignment of objectives" and "lack of leadership engagement" were validated in the Construct Management Aspects. Analyzing all the averages, it is observed that these factors were the ones with the highest intensities (averages between 7.7 and 8.2). These three factors are related to each other and are associated with the role played by the company's top management. Bueno (2005) and Erwin 
and Garman (2010) note that communication must be clear and assertive in all levels of the organization, thus ensuring a clear understanding of the objectives resulting in a greater chance of engagement.

The validation of these nine factors in three constructs can assist the top management of the steel company in future organizational changes and allow better results. The variables identified impact the routine of companies. Thus, they must be addressed. Although the results focus on a company, the methodological procedure used in this study can be replicated to evaluate the perception of employees in other companies and other countries.

It is also interesting to debate about other researches that analyzed quantitatively the process of organizational change. Van den Heuvel et al. (2017) analyzed the impact of quality in change information in workers attitudes regarding organizational change. For this, the authors calculated the regression weights and coefficients of determination. The authors showed the importance of change information for employees' attitudes in organizational changes. Through a multiple regression analysis, Spagnoli and Balducci (2017) evaluated the impact of organizational change on bullying at the workplace and found that high levels of workload and job insecurity contribute to workplace bullying. In both research quantitative approaches were used as a mean to understand different realities.

Organizational change is a business process that must be more explored. Studies presenting different realities and impacts caused by organizational change are necessary. In this sense, this article contributes to the literature showing a quantitative approach to evaluate the main factors that influence the processes of organizational change. 


\section{Conclusions}

The main objective of this article was characterized by the analysis of the main factors that influence the processes of organizational change in a company in the steel sector and, as presented, it is possible to affirm that objective was reached. Nine consensus factors that impact processes of organizational change in this company were identified. Special attention should be given by the top management of the steel company in these nine validated factors.

The results of this research are extremely valuable for the company studied and for other managers interested in the thematic "organizational change". Managers from other companies can use the steps presented in this article as procedure to conduct a similar assessment and determine the factors that impact organizational change in their companies. Also, these results may contribute to the development of a model on organizational change in future researches.

It is important to emphasize that this research has an exploratory character and aims to broaden the debates about ways to measure the main factors that impact the processes of organizational change. In no way the authors of this article intend to define the steps presented here as the only form to evaluate the main factors that impact the processes of organizational change. However, it can be an interesting path to be followed to analyze other realities.

\section{References}

Abdul Rashid, Z., Sambasivan, M. and Abdul Rahman, A. (2004), "The influence of organizational culture on attitudes toward organizational change", Leadership \& Organization Development Journal, Vol. 25 No. 2, pp. 161-179.

Al-Haddad, S. and Kotnour, T. (2015), "Integrating the organizational change literature: a model for successful change”, Journal of Organizational Change Management, Vol. 28 
No. 2, pp. 234-262.

Alavi, S.B. and Gill, C. (2017), "Leading Change Authentically: How Authentic Leaders Influence Follower Responses to Complex Change”, Journal of Leadership and Organizational Studies, Vol. 24 No. 2, pp. 157-171.

Berkhout, F. (2012), “Adaptation to climate change by organizations”, Wiley Interdisciplinary Reviews: Climate Change, January, Vol. 3 No. 1, pp. 91-106.

Bhatnagar, J., Budhwar, P., Srivastava, P. and Saini, D.S. (2010), “Organizational change \& development in India: A case of strategic organizational change and transformation", Journal of Organizational Change Management, Vol. 23 No. 5, pp. 485-499.

Bordia, P., Hobman, E., Jones, E., Gallois, C. and Callan, V.J. (2004), “UNCERTAINTY DURING ORGANIZATIONAL CHANGE: TYPES, CONSEQUENCES, AND MANAGEMENT STRATEGIES”, Journal of Business and Psychology, Vol. 18 No. 4, pp. 507-532.

Briody, E., Meerwarth Pester, T. and Trotter, R. (2012), “A story’s impact on organizationalculture change", Journal of Organizational Change Management, Vol. 25 No. 1, pp. 6787.

Bueno, W. da C. (2005), “A comunicação empresarial estratégica: definindo os contornos de um conceito", Conexão - Comunicação e Cultura, Vol. 4 No. 7, pp. 11-20.

Canning, J. and Found, P.A. (2015), "The effect of resistance in organizational change programmes: A study of a lean transformation”, edited by Su Mi Dahlgaard-Park, Prof Jens J., P.International Journal of Quality and Service Sciences, Vol. 7 No. 2/3, pp. 274 
295.

Cesar, A.M.R.V.C. (2006), "Sentimentos de Apego e Perda em processos de Mudanças Organizacionais", Revista Brasileira de Gestao de Negocios, Vol. 8 No. 21, pp. 1-12.

Chin, W.W. (1998), "The partial least squares approach for structural equation modeling”, Marcoulides, G.A. (Ed.). Modern Methods for Business Research, Lawrence Erlbaum Associates, London, pp. 295-336.

Choi, M. (2011), “Employees' attitudes toward organizational change: A literature review”, Human Resource Management, July, Vol. 50 No. 4, pp. 479-500.

Cohen, J. (1988), Statistical Power Analysis for the Behavioral Sciences, 2nd ed., Psychology Press, New York.

Drummond, P., Araujo, F. and Borges, R. (2017), "Meeting halfway", Business Process Management Journal, Vol. 23 No. 5, pp. 936-956.

Erwin, D.G. and Garman, A.N. (2010), "Resistance to organizational change: linking research and practice”, Leadership \& Organization Development Journal, Vol. 31 No. 1, pp. 3956.

Fornell, C. and Larcker, D. (1981), "Evaluating structural equation models with unobservable variables and measurement error”, Journal of Marketing Research, Vol. 18 No. 3, pp. 3950.

Foster, R.D. (2010), "Resistance, justice, and commitment to change", Human Resource Development Quarterly, Vol. 21 No. 1, pp. 3-39.

Gover, L., Halinski, M. and Duxbury, L. (2015), "Is it Just Me? Exploring Perceptions of 
Organizational Culture Change", British Journal of Management, Vol. 00, pp. 1-16.

Hair, J.F., Hult, G.T.M., Ringle, C. and Sarstedt, M. (2014), A Primer on Partial Least Squares Structural Equation Modeling (PLS-SEM), Sage Publications, Thousand Oaks.

Harris, L.C. and Ogbonna, E. (1998), "Employee responses to culture change efforts", Human Resource Management Journal, Vol. 8 No. 2, pp. 78-92.

Henseler, J., Ringle, C.M. and Sinkovics, R.R. (2009), “Advances in international marketing”, International Journal of Research in Marketing, Vol. 20, pp. 277-319.

van den Heuvel, S., Freese, C., Schalk, R. and van Assen, M. (2017), "How change information influences attitudes toward change and turnover intention: The role of engagement, psychological contract fulfillment, and trust", Leadership and Organization Development Journal, Vol. 38 No. 3, pp. 398-418.

Jacobs, G., van Witteloostuijn, A. and Christe-Zeyse, J. (2013), “A theoretical framework of organizational change”, Journal of Organizational Change Management, Vol. 26 No. 5 , pp. 772-792.

Jansson, N. (2013), “Organizational change as practice: a critical analysis", Journal of Organizational Change Management, Vol. 26 No. 6, pp. 1003-1019.

Kala Kamdjoug, J.R., Nguegang Tewamba, H.J. and Fosso Wamba, S. (2018), “IT capabilities, firm performance and the mediating role of ISRM: A case study from a developing country", Business Process Management Journal, available at:https://doi.org/10.1108/BPMJ-11-2017-0297.

Kalyani, M. and Prakashan Sahoo, M. (2011), "Human Resource Strategy: A Tool of Managing 
Change for Organizational Excellence", International Journal of Business and Management, Vol. 6 No. 8, pp. 280-286.

Van Knippenberg, B., Martin, L. and Tyler, T. (2006), "Process-orientation versus outcomeorientation during organizational change: The role of organizational identification", Journal of Organizational Behavior, Vol. 27, pp. 685-704.

Lee, R.G. and Dale, B.G. (1998), “Business process management: a review and evaluation”, Business Process Management Journal, Vol. 4 No. 3, pp. 214-225.

Leitão, S. dos S. and Domenico, S.M.R. de. (2015), "Looking at organizational change through the construction and reconstruction of the underpinning values of the organization through interactions among stakeholders”, Revista Brasileira de Gestao de Negocios, Vol. 17 No. 55, pp. 959-986.

Lewis, D.S. (1994), “Organizational Change: Relationship between Reactions, Behaviour and Organizational Performance", Journal of Organizational Change Management, Vol. 7 No. 5, pp. 41-55.

Luscher, L.S., Lewis, M. and Ingram, A. (2006), “The social construction of organizational change paradoxes", Journal of Organizational Change Management, Vol. 19 No. 4, pp. $491-502$.

Maheshwari, S. and Veena Vohra. (2015), "Identifying critical HR practices impacting employee perception and commitment during organizational change", Journal of Organizational Change Management, Vol. 28 No. 5, pp. 872-894.

Nery, V. de F. and Neiva, E.R. (2015), "Variáveis de Contexto e Respostas á Mudança 
Organizacional: Testando o Papel Mediador das Atitudes”, Psicologia: Teoria e Pesquisa, Vol. 31 No. 2, pp. 259-268.

Orsi, A. (2006), “Gestão do conhecimento em fusões e aquisições: Fatores críticos”, Revista Brasileira de Gestao de Negocios, Vol. 8 No. 22, pp. 46-56.

Pitsakis, K., Biniari, M.G. and Kuin, T. (2012), "Resisting change: organizational decoupling through an identity construction perspective", Journal of Organizational Change Management, Vol. 25 No. 6, pp. 835-852.

Ringle, C.M., Da Silva, D. and Bido, D.D.S. (2014), "Structural Equation Modeling with the Smartpls", Revista Brasileira de Marketing, Vol. 13 No. 02, pp. 56-73.

Rivera, J.R., Domenico, S.M. and Sauaia, A.C. (2014), "Influência da Dissimilaridade de Valores Individuais no Resultado de Times de Alta Gerência: um estudo em laboratório de gestão", Review of Business Management, May, Vol. 16 No. 50, pp. 60-74.

Seo, My., Taylor, M.S., Hill, N.S., Zhang, Xi., Tesluk, P.E. and Lorinkova, N. (2012), “THE ROLE OF AFFECT AND LEADERSHIP DURING RADICAL ORGANIZATIONAL CHANGE.”, PERSONNEL PSYCHOLOGY, August, Vol. 65, pp. 121-165.

Sidorova, A. and Isik, O. (2010), "Business process research: A cross-disciplinary review”, Business Process Management Journal, Vol. 16 No. 4, pp. 566-597.

Smith, M.E. and Mourier, P. (1999), “Implementation: Key to organizational change”, Strategy \& Leadership, Vol. 27, pp. 37-41.

Smollan, R.K. (2014), "Control and the emotional rollercoaster of organizational change", International Journal of Organizational Analysis, Vol. 22 No. 3, pp. 399-419. 
Smollan, R.K. (2015), "Causes of stress before, during and after organizational change: a qualitative study", Journal of Organizational Change Management, Vol. 28 No. 2, pp. $301-314$

Soparnot, R. (2011), "The concept of organizational change capacity", Journal of Organizational Change Management, Vol. 24 No. 5, pp. 640-661.

Spagnoli, P. and Balducci, C. (2017), "Do high workload and job insecurity predict workplace bullying after organizational change?", International Journal of Workplace Health Management, Vol. 10 No. 1, pp. 2-12.

Veit, D.R., Lacerda, D.P., Camargo, L.F.R., Kipper, L.M. and Dresch, A. (2017), "Towards Mode 2 knowledge production”, Business Process Management Journal, Vol. 23 No. 2, pp. 293-328.

Will, M.G. (2015), "Successful organizational change through win-win How change managers can create mutual benefits", Journal of Accounting \& Organizational Change, Vol. 11 No. 2, pp. 193-214.

Xu, X., Payne, S.C., Horner, M.T. and Alexander, A.L. (2016), "Individual difference predictors of perceived organizational change fairness", Journal of Managerial Psychology, Vol. 31 No. 2, pp. 420-433. 
Appendix 1. Questionnaire

\section{Respondents data:}

Have you participated in any process of change in the organization? How many times?

How old are you?

How long have you been working at this company?

What is your job position within the organization?

What area do you currently work in?

\section{Observations:}

1. During the change process, it is noticed that the employees are afraid, and this is a challenge for implementation successful.

2. With changes, new forms of work are needed. In this context, the anxiety and insecurity of employees provide greater resistance to change.

3. During changes in the company, feelings of suffering and stress arise for everyone to accept that change is needed.

4. The most negative people in the changes are those who have their lowest self-esteem.

5. At the beginning of the change process people have negative attitudes, and only after they realize some benefit they can change their attitudes.

6. With the changes, the current routines are changed creating discomfort for the execution of tasks.

7. People with bad experiences in previous changes always have negative reactions to accepting the changes.

8. People with a lot of time performing the same functions, on condition of comfort, will certainly not notice the improvements of the changes.

9. During changes, if there is low interaction among the various areas of the company, the acceptance of changes will also be low. 
10. In any change process, when there is rivalry among departments, the difficulty of implementing changes is evident.

11. Resistance to change is more related to personal beliefs and values than corporate beliefs and values.

12. When there are different cultures within the same company, all change deployment is too stressful to provide benefits.

13. When the company has low risk tolerance, changes acceptance is also low.

14. Departments that are underperforming and overly concerned with consensus are also more resilient to change.

15. When there is no record of "changes success and failures stories" acceptance to change is small for lack of lessons learned.

16. When the culture of collaboration is low, the attitude of acceptance for change is also low.

17. The lack of clarity in the communication through which changes occur increases the resilience of the change process.

18. The lack of alignment of objectives between the team and management makes the process of change implementation difficult.

19. The lack of opportunity to give an opinion during the change process reinforces the negative reaction to change attitude.

20. The lack of creativity stimulation is a factor that hinders change.

21. The lack of leadership committed to change also reflects the resistance to change in the team.

22. When there is low confidence in teams, resistance to change is greater.

23. When change is imposed by senior management its implementation can happen, but it is not sustainable.

24. The lack of a method for guiding and assessing the impact of change (change management strategy) makes it difficult to implement changes. 
Table 1. Factors that influence the processes of organizational change according to the literature (See references in table)

\begin{tabular}{|c|c|c|c|c|c|}
\hline \multicolumn{2}{|c|}{ Behavioral Aspects } & \multicolumn{2}{|c|}{ Cultural Aspects } & \multicolumn{2}{|c|}{ Management Aspects } \\
\hline Observed Factors & References & Observed Factors & References & Observed Factors & References \\
\hline $\begin{array}{c}\text { A1 }=\text { Fear of the } \\
\text { unknown }\end{array}$ & $\begin{array}{l}\text { (Abdul Rashid et } \\
\text { al., 2004; Jansson, } \\
\text { 2013; Smollan, } \\
\text { 2014) }\end{array}$ & $\begin{array}{l}\mathrm{B} 1=\text { Low } \\
\text { interaction (people } \\
\text { and departments) }\end{array}$ & $\begin{array}{l}\text { (Abdul Rashid et } \\
\text { al., 2004; Lewis, } \\
\text { 1994; Soparnot, } \\
\text { 2011) }\end{array}$ & $\begin{array}{l}\mathrm{C} 1 \text { = Lack of } \\
\text { clarity in } \\
\text { communications }\end{array}$ & $\begin{array}{l}\text { (Canning \& Found, } \\
\text { 2015; Erwin \& } \\
\text { Garman, 2010; Seo } \\
\text { et al., 2012; } \\
\text { Soparnot, 2011) }\end{array}$ \\
\hline $\begin{array}{c}\mathrm{A} 2=\text { Insecurity } \\
\text { and anxiety }\end{array}$ & $\begin{array}{l}\text { (Bordia et al., 2004; } \\
\text { Canning \& Found, } \\
\text { 2015; Lewis, 1994; } \\
\text { Smollan, 2014) }\end{array}$ & $\begin{array}{c}\mathrm{B} 2=\text { Competitions } \\
\text { and rivalries }\end{array}$ & $\begin{array}{c}\text { (Abdul Rashid et } \\
\text { al., 2004; Briody et } \\
\text { al., 2012) }\end{array}$ & $\begin{array}{l}\mathrm{C} 2=\text { Lack of } \\
\text { alignment of } \\
\text { objectives }\end{array}$ & $\begin{array}{c}\text { (Al-Haddad \& } \\
\text { Kotnour, 2015; } \\
\text { Kalyani \& } \\
\text { Prakashan Sahoo, } \\
\text { 2011; Maheshwari } \\
\text { \& Veena Vohra, } \\
\text { 2015; Will, 2015) }\end{array}$ \\
\hline $\begin{array}{l}\text { A3 = Stress and } \\
\text { feeling of } \\
\text { suffering }\end{array}$ & $\begin{array}{l}\text { (Bordia et al., 2004; } \\
\text { Maheshwari \& } \\
\text { Veena Vohra, 2015; } \\
\text { Smollan, 2014) }\end{array}$ & $\begin{array}{l}\mathrm{B} 3= \\
\text { Misalignments of } \\
\text { beliefs and values }\end{array}$ & $\begin{array}{l}\text { (Canning \& Found, } \\
\text { 2015; Choi, 2011; } \\
\text { Jacobs et al., 2013; } \\
\text { Rivera et al., 2014; } \\
\text { Seo et al., 2012) }\end{array}$ & $\begin{array}{l}\text { C3 = Lack of } \\
\text { opportunity to } \\
\text { comment }\end{array}$ & $\begin{array}{l}\text { (Canning \& Found, } \\
\text { 2015; Erwin \& } \\
\text { Garman, 2010; } \\
\text { Smollan, 2014) }\end{array}$ \\
\hline $\begin{array}{c}\text { A4 = Low self- } \\
\text { esteem }\end{array}$ & $\begin{array}{l}\text { (Canning \& Found, } \\
\text { 2015; Choi, 2011; } \\
\text { Smollan, 2014; Van } \\
\text { Knippenberg et al., } \\
\text { 2006) }\end{array}$ & $\begin{array}{l}\text { B4 = Multi } \\
\text { cultures in the } \\
\text { same company }\end{array}$ & $\begin{array}{l}\text { (Abdul Rashid et } \\
\text { al., 2004; Jacobs et } \\
\text { al., 2013; Van } \\
\text { Knippenberg et al., } \\
\text { 2006) }\end{array}$ & $\begin{array}{l}\mathrm{C} 4=\text { Lack of } \\
\text { creativity } \\
\text { stimulation }\end{array}$ & $\begin{array}{l}\text { (Maes \& Van } \\
\text { Hootegem, 2011; } \\
\text { Seo et al., 2012; } \\
\text { Soparnot, 2011) }\end{array}$ \\
\hline $\begin{array}{c}\text { A5 }=\text { Perception } \\
\text { of benefits }\end{array}$ & $\begin{array}{l}\text { (Erwin \& Garman, } \\
\text { 2010; Luscher et al., } \\
\text { 2006; Seo et al., } \\
\text { 2012; Will, 2015) }\end{array}$ & $\begin{array}{l}\text { B5 = Low degree } \\
\text { of risk acceptance }\end{array}$ & $\begin{array}{c}\text { (Berkhout, 2012; } \\
\text { Nery \& Neiva, } \\
\text { 2015) }\end{array}$ & $\begin{array}{l}\text { C5 = Lack of } \\
\text { leadership } \\
\text { engagement }\end{array}$ & $\begin{array}{c}\text { (Briody et al., } \\
\text { 2012; Smollan, } \\
\text { 2014; Van } \\
\text { Knippenberg et al., } \\
\text { 2006) }\end{array}$ \\
\hline $\begin{array}{c}\text { A6 }=\text { Feeling of } \\
\text { loss of control }\end{array}$ & $\begin{array}{l}\text { (Cesar, 2006; Erwin } \\
\text { \& Garman, 2010; } \\
\text { Will, 2015) }\end{array}$ & $\begin{array}{c}\text { B6 }=\text { Acceptance } \\
\text { of low } \\
\text { performance and } \\
\text { excessive concerns } \\
\text { with consensus } \\
\end{array}$ & $\begin{array}{l}\text { (Abdul Rashid et } \\
\text { al., 2004) }\end{array}$ & $\begin{array}{l}\text { C6 = Lack of } \\
\text { confidence }\end{array}$ & $\begin{array}{l}\text { (Bhatnagar et al., } \\
\text { 2010; Canning \& } \\
\text { Found, 2015; Erwin } \\
\text { \& Garman, 2010; } \\
\text { Seo et al., 2012) }\end{array}$ \\
\hline $\begin{array}{l}\mathrm{A} 7=\mathrm{Bad} \\
\text { experiences from } \\
\text { previous changes }\end{array}$ & $\begin{array}{l}\text { (Briody et al., 2012; } \\
\text { Canning \& Found, } \\
\text { 2015; Seo et al., } \\
\text { 2012) }\end{array}$ & $\begin{array}{l}\text { B7 = Lack of } \\
\text { record and history } \\
\text { about successes } \\
\text { and failures }\end{array}$ & $\begin{array}{l}\text { (Briody et al., 2012; } \\
\text { Canning \& Found, } \\
\text { 2015; Choi, 2011) }\end{array}$ & $\mathrm{C} 7=\underset{\text { Change }}{\text { Imposition of }}$ & $\begin{array}{c}\text { (Al-Haddad \& } \\
\text { Kotnour, 2015; } \\
\text { Foster, 2010; Orsi, } \\
\text { 2006; Will, 2015) }\end{array}$ \\
\hline A8 $=$ Comodism & $\begin{array}{l}\text { (Gover et al., 2015; } \\
\text { Harris \& Ogbonna, } \\
1998)\end{array}$ & $\begin{array}{c}\mathrm{B} 8=\mathrm{Low} \\
\text { collaborative } \\
\text { culture }\end{array}$ & $\begin{array}{c}\text { (Briody et al., 2012; } \\
\text { Cesar, 2006; } \\
\text { Soparnot, 2011) }\end{array}$ & $\begin{array}{l}\mathrm{C} 8=\text { Lack of a } \\
\text { method for change } \\
\text { guidelines }\end{array}$ & $\begin{array}{c}\text { (Briody et al., } \\
\text { 2012; Foster, 2010; } \\
\text { Gover et al., 2015) }\end{array}$ \\
\hline
\end{tabular}


Table 2. Parameters for the validated template (Source: authors)

\begin{tabular}{|c|c|c|c|c|}
\hline Constructs & AVE & Cronbach's Alpha & $\begin{array}{c}\text { Composite } \\
\text { Reliability }\end{array}$ & $\mathbf{R}^{\mathbf{2}}$ \\
\hline $\begin{array}{c}\text { Behavioral } \\
\text { Aspects }\end{array}$ & 0.700787 & 0.787078 & 0.874946 & 0.454976 \\
\hline Cultural Aspects & 0.560706 & 0.617508 & 0.791703 & 0.51712 \\
\hline $\begin{array}{c}\text { Management } \\
\text { Aspects }\end{array}$ & 0.752946 & 0.835708 & 0.90132 & 0.671742 \\
\hline
\end{tabular}


Table 3. Discriminant validity using criteria proposed by Chin (1998). Source: Authors

\begin{tabular}{|c|c|c|c|}
\hline Variables & Behavioral Aspects & Cultural Aspects & Management Aspects \\
\hline $\mathbf{A 1}$ & $\underline{\mathbf{0 . 8 4 8 9 4 8}}$ & 0.237317 & 0.289822 \\
\hline $\mathbf{A 2}$ & $\underline{\mathbf{0 . 8 9 4 2 2 1}}$ & 0.247786 & 0.284929 \\
\hline $\mathbf{A 3}$ & $\underline{\mathbf{0 . 7 6 2 9 0 0}}$ & 0.178196 & 0.099775 \\
\hline B4 & 0.328138 & $\underline{\mathbf{0 . 8 2 2 4 3 2}}$ & 0.417015 \\
\hline B5 & 0.030274 & $\underline{\mathbf{0 . 7 5 0 7 0 3}}$ & 0.327928 \\
\hline B6 & 0.197588 & $\underline{\mathbf{0 . 6 6 4 9 5 8}}$ & 0.151756 \\
\hline C1 & 0.185099 & 0.28880 & $\underline{\mathbf{0 . 8 4 6 5 5}}$ \\
\hline C2 & 0.263439 & 0.381573 & $\underline{\mathbf{0 . 9 0 6 4 3 4}}$ \\
\hline C5 & 0.278080 & 0.416055 & $\underline{\mathbf{0 . 8 4 8 8 6 4}}$ \\
\hline
\end{tabular}


Table 4. Discriminant validity using criteria proposed by Fornell and Larcker (1981). Source: Authors

\begin{tabular}{|c|c|c|c|}
\hline Constructs & Behavioral Aspects & Cultural Aspects & $\begin{array}{c}\text { Management } \\
\text { Aspects }\end{array}$ \\
\hline Behavioral Aspects & $\underline{\mathbf{0 . 8 3 7 1 3 0}}$ & & \\
\hline Cultural Aspects & 0.267541 & $\underline{\mathbf{0 . 7 4 8 8 0 3}}$ & \\
\hline Management Aspects & 0.281826 & 0.420721 & $\underline{\mathbf{0 . 8 6 7 7 2 5}}$ \\
\hline R Square & 0.454976 & 0.51712 & 0.671742 \\
\hline
\end{tabular}


Table 5. t-student values for the model (Source: authors)

\begin{tabular}{|c|c|c|c|c|}
\hline Variables & Behavioral Aspects & Cultural Aspects & $\begin{array}{c}\text { Management } \\
\text { Aspects }\end{array}$ & $\begin{array}{c}\text { Organizational } \\
\text { Changes }\end{array}$ \\
\hline A1 & 20.295557 & & & 8.629103 \\
\hline $\mathbf{A 2}$ & 13.979240 & & & 7.499049 \\
\hline $\mathbf{A 3}$ & 8.468955 & & & 4.221416 \\
\hline $\mathbf{B 4}$ & & 25.317307 & & 11.923791 \\
\hline B5 & & 12.255052 & & 5.581776 \\
\hline B6 & & 6.348847 & & 3.947922 \\
\hline C1 & & & 22.128446 & 10.710796 \\
\hline C2 & & & 47.838920 & 17.323501 \\
\hline C5 & & & 29.995806 & 16.816489 \\
\hline
\end{tabular}


Table 6. Predictive Validity $\left(\mathrm{Q}^{2}\right)$ and Effect Size $\left(\mathrm{f}^{2}\right)$ for the model (Source: authors)

\begin{tabular}{|c|c|c|}
\hline Constructs & Predictive Validity $\left(\mathrm{Q}^{2}\right)$ & Effect Size $\left(\mathrm{f}^{2}\right)$ \\
\hline Behavioral Aspects & 0.311662 & 0.602956 \\
\hline Cultural Aspects & 0.276101 & 0.465549 \\
\hline Management Aspects & 0.499078 & 0.652894 \\
\hline Organizational Changes & 0.367535 & 0.367535 \\
\hline
\end{tabular}


Table 7. Factors validated by the SEM (Source: authors)

\begin{tabular}{|c|c|c|c|}
\hline Construct & & Variables & Average \\
\hline \multirow{3}{*}{$\begin{array}{l}\text { Behavioral } \\
\text { Aspects }\end{array}$} & A1 & Fear of the unknown & 6.3 \\
\hline & $\mathbf{A 2}$ & Insecurity and anxiety & 6.3 \\
\hline & $\mathbf{A 3}$ & Stress and feeling of suffering & 5.9 \\
\hline \multirow{3}{*}{ Cultural Aspects } & B4 & Multi cultures in the same company & 6.6 \\
\hline & B5 & Low degree of risk acceptance & 6.3 \\
\hline & B6 & $\begin{array}{c}\text { Acceptance of low performance and excessive concerns } \\
\text { with consensus }\end{array}$ & 6.1 \\
\hline \multirow{3}{*}{$\begin{array}{l}\text { Management } \\
\text { Aspects }\end{array}$} & C1 & Lack of clarity in communications & 8.2 \\
\hline & $\mathbf{C 2}$ & Lack of alignment of objectives & 8.0 \\
\hline & C5 & Lack of leadership engagement & 7.7 \\
\hline
\end{tabular}




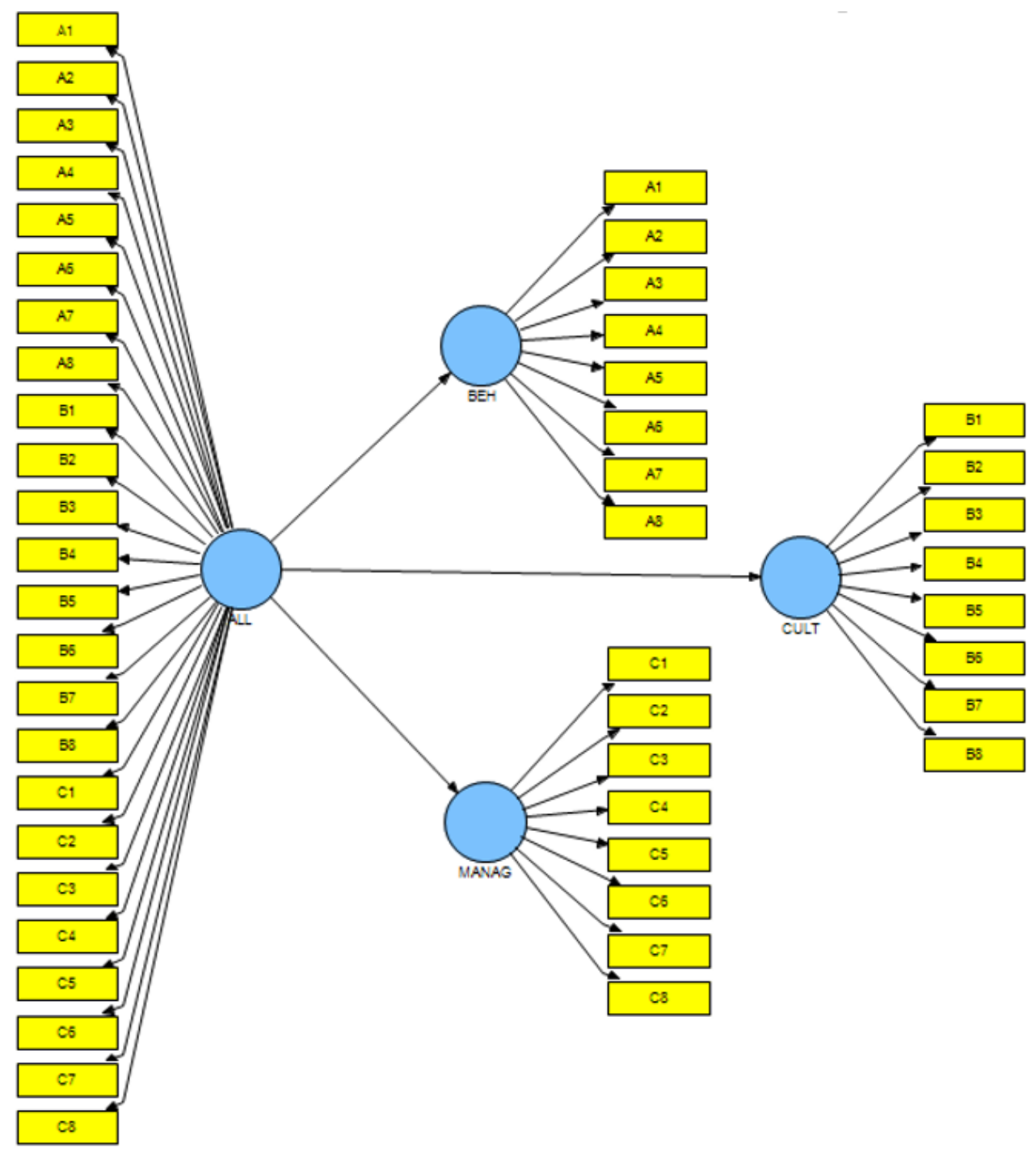

Figure 1. Initial model proposed (Source: Authors) 


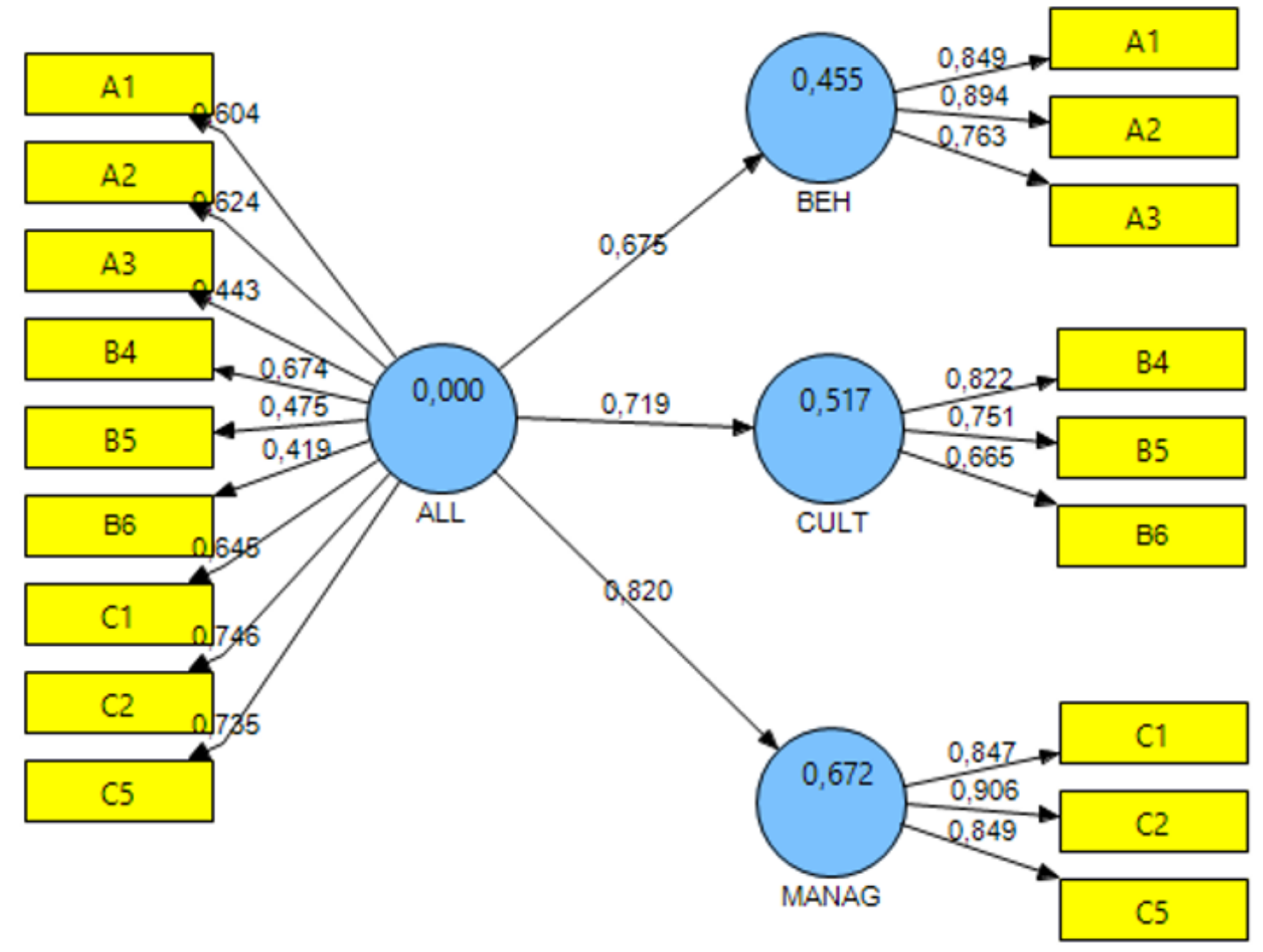

Figure 2. Validated model (Source: authors) 